\title{
Attitudes and Perceptions of the Local Community towards Sustainable Tourism Development in Kurdistan Regional Government, Iraq
}

\author{
Rezhen Harun ${ }^{1}$, Gabriela O. Chiciudean ${ }^{2}$, Kawan Sirwan ${ }^{1}$, Felix H. Arion ${ }^{2}$ (D) and \\ Iulia C. Muresan 2,* (D) \\ 1 Department of Agribusiness and Rural Development, College of Agricultural Sciences, \\ University of Sulaimani, Kurdistan Regional Government-Iraq, Sulaimani-Bakrajo 5100, Iraq; \\ rezhen.rashid@univsul.edu.iq (R.H.); kawan.ismael@univsul.edu.iq (K.S.) \\ 2 Department of Economic Sciences, University of Agricultural Sciences and Veterinary Medicine \\ Cluj-Napoca, 3-5 Manastur Street, Cluj-Napoca 400372, Romania; \\ gabriela.chiciudean@usamvcluj.ro (G.O.C.); felixarion@usamvcluj.ro (F.H.A.) \\ * Correspondence: iulia.muresan@usamvcluj.ro; Tel.: +40-721-64-31-36
}

Received: 21 July 2018; Accepted: 21 August 2018; Published: 23 August 2018

\begin{abstract}
Over the last years, tourism has undergone significant development worldwide, especially in developing countries. Tourism is a multi-faced activity with positive and negative impacts on the destinations, linking the economic, social, and environmental components of sustainable development. The attitude of the host community is an important factor for future tourism planning, management, and development of a tourism destination. As such, the paper analyzes the attitudes and perceptions of the local residents from the Kurdistan Regional Government, located in the northern part of the Republic of Iraq. To achieve the purpose of the research, a survey based on a questionnaire was conducted in Sulaimani and Halabja Governorates. A number of 320 questionnaires were applied in 2016. The collected data were analyzed using descriptive statistics and principal component analysis. The results indicate that tourism is seen as a development sector during the last years. Its positive impacts are better perceived than the negative ones, mainly because it offers more recreational opportunities due to the development of new recreational parks. Tourism increases pollution, this being the most negative aspect mentioned by the respondents, but regardless, they are proud of the progress overthe last years and they support future actions for tourism development.
\end{abstract}

Keywords: sustainable tourism; tourism impacts; residents' attitude; destination management; cluster analysis

\section{Introduction}

There is no doubt that over the last years, the tourism industry underwent significant development worldwide with important consequences at top levels of decision-making due to the importance of the attitudes and perceptions of the local communities for sustainable tourism planning strategies. Understanding the impact of tourism on the local communities is becoming a major topic for researchers, while being the key element in building sustainable and long-term tourism strategies [1-6]. Consulting and involving the local community whenever tourism strategies are built, increases their success rate and assures positive effects in important areas: economic, social, cultural, and environmental [7]. So, locals' support has became an important issue for researchers [8-12].

Recently, the local community has become one of the most important stakeholders of the tourism industry [13-17]. Its active participation and involvement is essential for a successful tourism 
product [18]. It was pointed out well that tourism is a "double-edged sword" because it involves both positive and negative aspects for the host communities [19].

Eshliki and Kaboudi [13] stated that the degree of host community participation in tourism is strongly related to the perceived tourism effects, and Hanafiah et al. [20] concluded that participation is connected to personal benefits obtained from tourism. This approach is actually the essence of the social exchange theory applied in tourism, which explains the community attitude and involvement based on the benefits obtained, whether they are economic, socio-cultural or environmental [21]. If costs are greater than the benefits obtained, residents will oppose tourism activity, but if they can benefit from this activity without substantial cost, they are likely to support it [22]. This theory was tested among many communities around the world where tourism activities exist, using the three main pillars of sustainability: economic, socio-cultural, and environmental [3,19,23-26]. After conducting a complex literature review on the social exchange theory and its applicability in tourism, some scholars recommend it as the "prevalent theory" [27].

Host communities generally perceive tourism activities positively within their region, especially because of the economic benefits, including job opportunities, which is, by far, the most important $[18,20,25,28-31]$. Socio-cultural aspects are generally perceived positively too, mainly because of public facilities created by local authorities [16,32]. The environmental component of the social exchange theory is often perceived by the host community in negative terms, because of some the costs brought on by tourism development like pollution, crowding, destruction of natural habitats, noise, etc. [17,25,33-35].

Understanding local community knowledge about rural tourism development, its beliefs, and awareness of its benefits on their welfare helps policymakers developing and implementing long term sustainable strategies. This paper aimed to investigate rural community perceptions regarding the tourism development during the last years in the Kurdistan Regional Government Region. The research was conducted in the context of the increasing need of the population for recreational activities and the recent development of new tourist sights in the region. It was considered opportune since it offers valuable information for future tourism, and not only in terms of general infrastructure and security), but also in development plans of the region.

This paper consists of six sections. After the introduction, the Section 2 presents the literature review regarding tourism development impacts and local communities' perceptions. The third section "Materials and Methods" describes the research area and the methods used for the data analysis. Furthermore, the fourth section is dedicated to the results of the study and comprises two sub-sections "Perceptions on Tourism Impact Development" and "Analysis of the Link between Respondents' Demographic Profile and Tourism Support". The fifth section is dedicated to the discussion of the results, while the last section of the article presents the main conclusions, limitations, and future research directions.

\section{Literature Review}

Although studies were conducted in many countries, it is useful to focus on those regions that are geographically similar to Kurdistan, where little research has been made about this topic, as most studies refer to different regions of Iran. A common issue of the research conducted in Eastern countries is the fact that communities support tourism activities and the main reasons consist not only of the economic benefits (e.g., job creation, support for local economy, etc.) but social ones too, like interaction with tourists and public services improvement. The negative impacts of tourism development, particularity the moral issues, have high impact on the youngsters' behavior [36].

Demographic variables, especially gender, age, and education are important factors that influence residents' perception. In some cases, an important predictor of host community perception is the length of residency within the community [16,37]. Furthermore, a less supportive attitude towards tourism because of the government political and fiscal system was noticed in the Ugrup region, Turkey [38]. A study conducted in Kemer (Turkey) using cluster analysis obtained five clusters, among which 
"community public service focused" was the largest and most female dominant. Another important finding consisted in the fact that the older population is favorable to tourism development, but not interested in environmental issues [39].

A favorable attitude towards tourism is related to the degree of dependence on tourism $[36,40]$, a fact observed in Masooleh, Iran [41] and also in Kashan, Iran, where tourism is appreciated for job opportunities and recreational facilities [32]. In Shiraz, Iran, the economic and environmental tourism impacts were positively evaluated even if aspects like noise, pollution, crime rate, and destruction of natural habitat were negatively evaluated [42]. Unlike other cases, the Egyptian residents do not consider that tourism development is responsible for traffic jams, noise, and pollution [43], but for worsening the living standard because of inflation, affecting local identity, and overcrowding tourism destinations. Tourism's impact is not always perceived positively, and a research of Eshliki and Kaboudi [13] among the Iranian community of Ramsar is proof: residents were very disturbed by the negative effects of tourism on the environment and also on the sociocultural life, causing a lower involvement in tourism activity.

In the region of Kermanshah, Iran, a particularity was encountered: unlike most of the communities which value tourism for its economic benefits, the community from Kermanshah perceived the sociocultural impacts favorably, followed by the environmental ones, and last the economic impacts, even if they recognize that tourism is a job creator [15]. The socio-cultural factor is the most positively evaluated because the community is very open to tourists, which they like to interact with and show their cultural heritage. Environmental impacts are also positively evaluated because the community hopes that tourism will contribute to restoring the cultural heritage, even if crowding, traffic problems, and noise are negatively perceived. Similar findings were noticed in Bisotun, Iran where the community evaluated the social factors most favorably, among which the interaction with tourists was considered to be very important [44]. The residents of Hawraman, Iran, with a higher level of community attachment and involvement, perceived tourism and its impact in a positive way, considering that it had a positive influence over the quality of life [45]. Residents from Mashhad Iran, a region known for religious tourism, perceived that tourism has a negative impact on the environment [46].

Interesting findings were obtained by Alhasanat and Hyasat [36] among the Jordanian population from Petra, where the level of education influenced the perception on tourism, in a way that less educated people evaluated the tourism activity positively, while more educated people, negatively, unlike the findings obtained by Abdollahzadeh and Sharifzadeh [4] in a study from Zyarat, Iran, where less educated people were unaware of tourism benefits and evaluated it negatively, while medium-educated people in a positive way. Closely related to education is the concept of "environmental literacy" part of the environmental education, which was analyzed in relation with willingness to pay for environmental attributes in the context of small islands tourism [47].

\section{Materials and Methods}

The study was conducted in the tourist rural area of the Governorates Sulaimani and Halabja, from Kurdistan Regional Government, in the northern part of the Republic of Iraq, during March-May 2016, in order to identify the attitudes and the perceptions of the rural residents toward tourism development in the area. For the Sulaimani Governorate, six tourist places were selected: Dukan, Tabin, Chami rezan, Zewe, Penjwen, and Sharbazher, while for the Halabja Governorate, for tourist places were selected: Ahmed Awa, Tawella, Biara, and Zallm. The selection of the tourist places was based on their attraction for the tourist and the projects that took place in the area during the past years. In the last years, an increase of tourism activity was noticed especially due to the region's high potential for religious tourism, cultural tourism, eco-tourism, and business tourism.

The Kurdistan Regional Government area is home to some of the most important sites in the world (e.g., cave shelters, sites from the Neolithic era, which witnessed the domestication of plants 
and animals, cities and settlements of great empires of antiquity, canals and rock reliefs, castles and bridges, mosques and bazaars) [48].

The quantitative survey based on a questionnaire was used in order to examine the locals' attitude and perception about tourism development. The field work was carried out between March-May 2016, based on a non-probability convenience sample of 320 rural residents. The survey was conducted in Kurdish based on face-to-face interviews, by four rained interviewers and supervised by two of the authors. A pilot study was conducted on a sample of 14 respondents in order to evaluate the feasibility of the research instrument. Based on the results of the pilot study some of the questions were removed (e.g., the one related to the monthly household income, occupation), while for others the evaluation scale was reduced from 7 points to 5 points. The final questionnaire comprised four main sections, from which three of them were analyzed and presented in the current paper. The fourth section which was not used for the purpose of the current paper, as it investigated the tourism entrepreneurship intention among rural residents. In the first section of the analyzed sections, 19 items were used in order to gather responses from local residents regarding their perception about the impact of tourism development; the second section comprised 3 items in order to determine their support for tourism development; the third section of the survey instrument was used to design the consumers' socio-demographic profile.

A descriptive statistical analysis was used to identify the profile of the local residents and to determine the means and standard deviation of each of the items used to describe the residents' perception and their support for tourism development. Exploratory factor analysis was employed to assess the factor structure of the variables that describe the residents' perception about tourism development. The 19 variables were factor-analyzed using principal component analysis (PCA) with the Varimax rotation method to establish the underlying constructs. The Kaiser-Meyer-Olkin (KMO) measure of sampling adequacy and Bartlett's test of Sphericity were examined to determine the fitness of the data. Cronbach's alpha reliability coefficient was computed for each factor to estimate the internal consistency of each scale. Following the factor analysis, a summated scale for each of the factors was generated by summing items loaded on each construct and deriving their average score. Subsequently, a confirmatory factor analysis (CFA) was conducted to test validity [49] via AMOS 23.0.

A cluster analysis was conducted in order to isolate different groups within the sample and examine their common features. A hierarchical cluster analysis using the Ward's algorithm identified 2 homogenous clusters in the overall sample. Furthermore K-means cluster, a non-hierarchical clustering technique was used. Cross-tabulation analysis using Person's $\chi^{2}$ statistics was performed with the demographic data, in order to determine the profile of the respondents from each group and if there are any significant differences among them. Subsequently, an independent $t$-test was employed to compare the different groups by analyzing the significant difference between their means.

\section{Results}

\subsection{Perceptions on Tourism's Impact on Development}

Principal factor analysis (PCA) was conducted to assess the dimensionality of the 19 items used to evaluate the perception of rural residents towards tourism development. A 5-point Likert-type scale was used based on the following scale: 1 = strongly disagree; 2 = disagree; $3=$ neutral; $4=$ agree; and $5=$ strongly agree to evaluate each variable. The Barlett's test of sphericity was significant (Chi-square $=2261.201, p<0.000)$. The Kaiser-Meyer-Olkin $(\mathrm{KMO})$ overall measure of sampling was 0.71 higher than 0.6 , indicating that data were suitable for the principal component analysis $[50,51]$. The PCA with Varimax rotation of the 19 variables resulted in a five-component solution that explains $60.24 \%$ of the total variance. Only the factors with Eigenvalues greater than 1.0 were accepted. In this study all the items that showed factor loading higher than 0.45 were retained for future analysis. Hair et al. [48] indicated that 0.45 factor loading score is sufficient for samples higher than 150 respondents (p. 128). The overall reliability of the 19 variables was 0.86 , higher than 0.6 
indicating that data are suitable for the analysis. The closer the Cronbach's alpha coefficient is to 1.00 the greater the internal consistency of the items in the scale [49,52]. The CFA results suggest good fit as follows: $\chi^{2}=260.358$, d.f. $=142\left(\chi^{2} /\right.$ d.f. $\left.=1.834\right), p<0.001$, NFI $=0.918$, TLI $=0.927$, $\mathrm{CFI}=0.912$, and RMSEA $=0.090$ [49]. The composite reliability $(\mathrm{CR})$ of the constructs was above 0.7 , with an average variance extract (AVE) higher than 0.5 , except for the fifth factor which did not meet the validity and reliability criteria [49]. Subsequently, the fifth factor was removed from further analysis.

Five perception variables (i.e., more vandalism, increase of crimes, increase of the cost of living, increase of litter, and change in the traditional culture) concerning the negative impacts of tourism development were loaded in the first component, and for counted $28.03 \%$ of the total variance (Table 1 ).

The first factor, labeled "negative impacts" had a mean of 3.38 (SD = 1.044) lower than the others found in similar research [21]. The residents tended to be more affected by the increase in the cost of living standards (mean $=3.66, \mathrm{SD}=1.362)$ and less affected by the change in their culture (mean $=3.24$, $\mathrm{SD}=1.383$ ), reinforcing the findings of Eraqi [43] (Table 2).

The second factor, labeled "social impacts", was loaded with five variables (i.e., development opportunity for the community, improve quality of life, increases standard of living, preserve the cultural identity, development of parks and recreation facilities) explained $12.05 \%$ of the total variance and had a mean of $3.96(\mathrm{SD}=0.682)$.

Table 1. Results of principal factor analysis (PCA) on perceptions of tourism impact development.

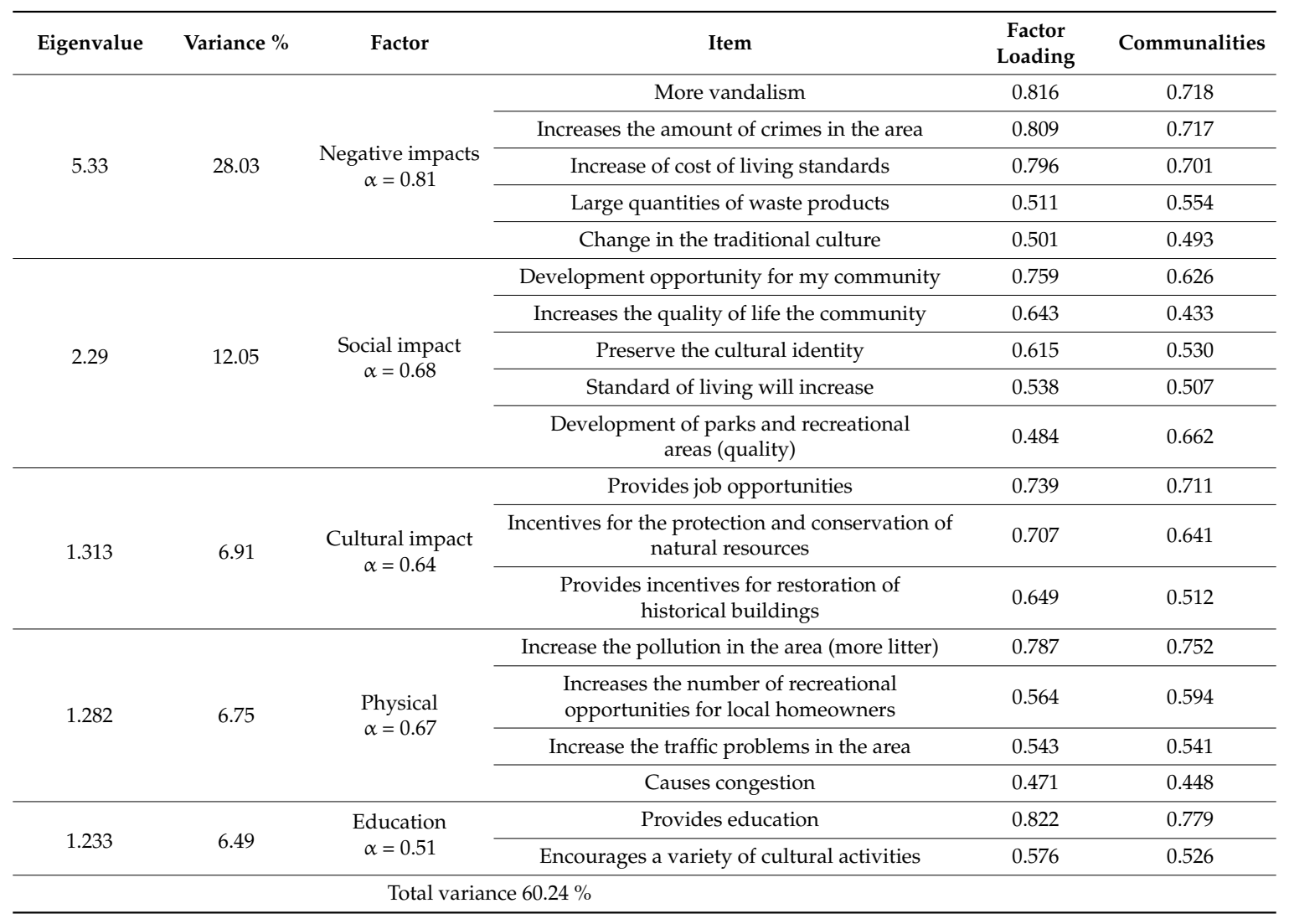

The third factor, labeled "cultural impacts", comprised of three variables, explained $6.91 \%$ of the variance and had a mean of $4.03(\mathrm{SD}=0.840)$. This factor involved attributes that focus on the protection and conservation of natural resources (mean $=3.94, \mathrm{SD}=1.114$ ) and restoration of historical buildings (mean $=3.99, \mathrm{SD}=1.073$ ). The fourth factor, called "physical", had four items: increase in pollution, new recreational opportunities, increase in traffic problems that lead to congestion in the area. This factor explained $6.75 \%$ of the variance and has a mean of $3.98(\mathrm{SD}=0.857)$. The rural 
residents perceived tourism as a factor that influences traffic jams (mean $=3.77, \mathrm{SD}=1.436$ ) and the pollution in their area (mean $=4.07, \mathrm{SD}=1.084)$ similar with the results of Aref et al. [42].

The fifth factor, named "education", comprised of two attributes, explained $6.49 \%$ of the variance and had a mean of $3.96(\mathrm{SD}=0.826)$ with a reliability coefficient of 0.51 . Residents agree that tourism development has a direct and positive effect on the quality and numbers of cultural events from the rural area, mainly because of the development of festivals (mean $=4.08, \mathrm{SD}=0.869$ ). Even if education is an important aspect in tourism development it was decided to remove this factor from the future analysis of the data, due to the low internal consistency of the scale.

Table 2. Perception on tourism development impact.

\begin{tabular}{ccc}
\hline Item & Mean & SD \\
Negative impacts & 3.38 & 1.044 \\
More vandalism & 3.24 & 1.378 \\
Increases the amount of crimes in the area & 3.30 & 1.354 \\
Increase of cost of living standards & 3.66 & 1.362 \\
Large quantities of waste products & 3.50 & 1.443 \\
Change in the traditional culture & 3.24 & 1.383 \\
Social impacts & 3.96 & 0.682 \\
Development opportunity for my community & 4.17 & 0.974 \\
Increases the quality of life the community & 3.93 & 0.871 \\
Preserve the cultural identity & 3.61 & 1.292 \\
Standard of living will increase & 3.90 & 1.069 \\
Cultural impacts & 4.24 & 0.870 \\
Provides job opportunities & 4.03 & 0.840 \\
Development of parks and recreational areas (quality) & 4.17 & 1.106 \\
Incentives for the protection and conservation of natural resources & 3.94 & 1.114 \\
Provides incentives for restoration of historical buildings & 3.99 & 1.073 \\
Physical & 3.98 & 0.857 \\
Increase the pollution in the area (more litter) & 4.06 & 1.084 \\
Increases the number of recreational opportunities for local homeowners & 4.28 & 0.978 \\
Increase the traffic problems in the area & 3.77 & 1.436 \\
Causes congestion & 3.81 & 1.283
\end{tabular}

The residents perceived tourism as a development opportunity for their community (mean $=3.93$, $\mathrm{SD}=0.871$ ), mainly because the development of new parks and recreational areas (mean $=4.24$, $\mathrm{SD}=0.870$ ) provides new job opportunities for the host community, and in the end increases the living standard of the residents (mean $=3.90, \mathrm{SD}=1.069)$ (Table 2).

The residents from rural Kurdistan Regional Government strongly agree that tourism development has a positive impact on the social (mean $=3.96, \mathrm{SD}=0.682$ ) and cultural components $($ mean $=4.03, \mathrm{SD}=0.840)$.

\subsection{Analysis of the Link between Respondents' Demographic Profile and Tourism Support}

Furthermore, four out of five factors (i.e., negative, social, cultural impacts, and physical) loaded after running the PCA were cluster analyzed (a Ward's hierarchical ascendant classification followed by a k-means clustering for stabilization purpose). It allowed the identification of two clusters. Multivariate statistics indicated that significant differences exist between the two clusters $(p<0.001)$ (Table 3). The factors with the higher influence on the clustering of the residents were the "negative impacts" and "physical" (Table 3). The clusters were named according to the members' perceptions about the tourism development impact. 
Cross-tabulation and Person's $\chi^{2}$ statistics was used to identify the profile of rural residents in terms of their gender, age, education level, and desire to invest in tourism and support for future tourism development.

The results indicated that the majority of the respondents were male and open to the idea of starting a business in tourism (Table 4). Cluster $1(n=190)$ was the largest one and represented $59.38 \%$ of the total population. This cluster was predominantly characterized by residents that believed that the development of tourism had a negative impact on physical facilities, but had a positive impact on the cultural aspects of the rural community. The cluster was consequently named "supporters of tourism development". Cluster $2(n=130)$ represents $40.62 \%$ of the total population. The second cluster characterized residents who were interested in the social and cultural effects of tourism development, but the difference from the first cluster was significant and thus, it was named "disinterested for tourism development" (Table 3).

Table 3. Clustering variables profiles.

\begin{tabular}{|c|c|c|c|c|}
\hline Factors & $\begin{array}{c}\text { Cluster } 1 \\
(n=190,59.38 \%)\end{array}$ & $\begin{array}{c}\text { Cluster } 2 \\
(n=130,40.62 \%)\end{array}$ & F Value & Significance \\
\hline Negative impacts & 4.05 & 2.41 & 474.408 & $0.000 *$ \\
\hline Social impacts & 4.26 & 3.53 & 117.088 & $0.000 *$ \\
\hline Cultural impacts & 4.29 & 3.50 & 119.048 & $0.000 *$ \\
\hline Physical & 4.47 & 3.27 & 284.476 & $0.000 *$ \\
\hline
\end{tabular}

Note: ${ }^{*} p<0.05$

Table 4. Demographic profile and tourism support.

\begin{tabular}{|c|c|c|c|}
\hline & Characteristics & Cluster I $(n=190)$ & Cluster II $(n=130)$ \\
\hline \multirow{3}{*}{ Gender } & Female & $65(34.2 \%)$ & $57(43.8 \%)$ \\
\hline & Male & $125(65.8 \%)$ & $73(56.2 \%)$ \\
\hline & \multicolumn{3}{|c|}{$\chi^{2}=15.153, \mathrm{df}=1, p=0.000$} \\
\hline \multirow{3}{*}{ Age } & & 37.08 & 28.47 \\
\hline & Years (mean) & $(9.794)^{\mathrm{a}}$ & $(10.288)^{a}$ \\
\hline & \multicolumn{3}{|c|}{$t(318)=7.566, p=0.000$} \\
\hline \multirow{7}{*}{ Education level } & Illiterate & $46(24.2 \%)$ & $21(16.6 \%)$ \\
\hline & Primary & $29(15.3 \%)$ & $0(0 \%)$ \\
\hline & Secondary & $15(7.9 \%)$ & $6(4.6 \%)$ \\
\hline & High school & $37(19.5 \%)$ & $18(13.8 \%)$ \\
\hline & Institution & $45(23.7 \%)$ & $25(19.2 \%)$ \\
\hline & University degree & $18(9.5 \%)$ & $60(46.2 \%)$ \\
\hline & \multicolumn{3}{|c|}{$\chi^{2}=68.227, \mathrm{df}=5, p=0.000$} \\
\hline \multirow{3}{*}{$\begin{array}{l}\text { Desire to invest in } \\
\text { tourism }\end{array}$} & Yes & $152(80 \%)$ & $78(60 \%)$ \\
\hline & No & $38(20 \%)$ & $52(40 \%)$ \\
\hline & \multicolumn{3}{|c|}{$\chi^{2}=15.273, \mathrm{df}=1, p=0.000$} \\
\hline \multirow{6}{*}{$\begin{array}{l}\text { Support for tourism } \\
\text { development }\end{array}$} & Importance of tourism for the community & $3.43^{\mathrm{b}}(1.060)^{\mathrm{a}}$ & $3.22^{b}(1.183)^{a}$ \\
\hline & \multicolumn{3}{|c|}{$t(318)=1.606, p=0.109$} \\
\hline & $\begin{array}{l}\text { I believe that tourism industry should be } \\
\text { actively encouraged in my community }\end{array}$ & $4.44^{\mathrm{c}}(0.772)^{\mathrm{a}}$ & $4.05^{\mathrm{c}}(1.051)^{\mathrm{a}}$ \\
\hline & \multicolumn{3}{|c|}{$t(221.24)=3.549, p=0.000$} \\
\hline & $\begin{array}{l}\text { I support tourism and would like to see it } \\
\text { become an important part of my community }\end{array}$ & $4.43^{c}(0.708)^{a}$ & $3.72^{c}(1.228)^{a}$ \\
\hline & \multicolumn{3}{|c|}{$t(187.664)=6.004, p=0.000$} \\
\hline
\end{tabular}

Note: "Standard deviation, " "not at all important" to "extremely important", c "totally disagree" to "totally agree".

The findings indicated that the "supporters of tourism development" cluster represents the majority of the population. This cluster includes the largest number of males compared with the other cluster $(65.8 \%)$ and older residents, with higher desire to invest in tourism business development, exhibiting statistically significant differences from the second cluster. 
Subsequently, an independent $t$-test was carried out to examine the influence of cluster membership on the support for future tourism development and the perceived importance of tourism for the future development of the community.

Referring to Table 4, the results show that residents from the first cluster differ significantly in their support for tourism development (mean $=3.43$ for perceived importance of tourism, mean $=4.44$ for encouraging tourism activity and mean $=4.43$ for tourism development support). A reason for this situation can be the fact that tourism can represent a viable alternative to use the extra resources from the agricultural activity (local products) and to attract young people to work in the rural area [53].

\section{Discussion}

Tourism was perceived as a development opportunity for the host community because of the main benefits (e.g., new parks and recreational areas, job opportunities, living standard of the residents). These results confirm the findings of previous studies showing that tourism development leads to environment protection (natural and cultural) and an increase in job opportunities [32,35,41]. These are important aspects for sustainable tourism development in rural areas. The development of tourism activity in rural areas generates extra income for the local budget that could be invested for future tourism development plans and conservation of the tourism attractions, ensuring the sustainability of the area.

The residents from rural Kurdistan Regional Government perceived tourism development being a key element with positive impact on the social and cultural components. The findings of this research are similar to those of other studies such as Andriotis and Kuvan and Akan [54,55]. The fact that tourism is perceived as having cultural benefits is a common finding in this geographical area, where host communities are very proud of their cultural heritage, being part of one of the oldest civilizations. Other studies from Iran indicate its' huge importance [15,44].

There are different findings regarding the link between the attitude and support for tourism development and the age of the respondents. In the current research, older residents perceived traffic jams, pollution more negatively in their attitudes toward tourism development compared with the youngest one, similar with the findings of Cavus and Tanrisevdi [56]. They realize and agree that tourism development leads to new entertainment options for the local community, with direct impact on the environment.

The first cluster entitled "supporters of tourism development" seems to be more aware of the impacts of tourism on sustainable development. The residents from this cluster are more preoccupied by the negative impacts of tourism development on the natural environment and on the culture of the area. The residents from Iran also perceived negatively the tourism impact over the environment [46]. They realized that the development of tourism activity will lead to an increase in the number of visitors with a direct impact on living cost, number of crimes, and quantity of litter in the area, on the one hand. On the other hand, they see tourism as a job creator and an opportunity for the development of the local community. At the same time, their attitude toward the cultural benefits of tourism development is more significant than the one of the cluster named "disinterested for tourism development", thus reinforcing the results of Deng et al. [57].

The "disinterested for tourism development" (the second cluster) cluster represents $40.62 \%$ of the respondents and has the highest number of females (43.8\%) compared with the first cluster. At the same time the respondents from this cluster are more educated and younger, with a lower desire to invest in the tourism business. Surprisingly, even if the respondents comprised in this cluster are more educated, their perception about the social and cultural impacts of tourism development is lower than the one of the respondents from the first cluster. Their support for tourism development is lower compared to the other group. This can be explained by the fact that traditionally, males are the ones involved in tourism activity (business men, workers) in the research area. Another explanation for the lower desire to invest in tourism business can be the age of the respondents. The entrepreneurial intentions are more often present among the middle age group, compared with others age groups $[58,59]$. 
The analysis of the characteristics of the two identified groups revealed that there are significant differences between the first and second cluster. The first cluster is more interested in tourism development and its impact on the natural, cultural and social aspects, while the second cluster seems not to care too much about tourism development and its impacts on the local community. This is surprising, since the second cluster is more educated $(46.2 \%$ of the members of this cluster have a university degree) and the members are younger. An explanation for this situation can be that young and educated rural residents do not see their future in the rural area, and they are looking for opportunities in the neighboring cities.

\section{Conclusions}

Based on its very old and rich heritage, with roots that go back until 5000-6000 BC, the Kurdish potential to attract tourism is significant. The tumultuous past that the Kurdistan region had to face left traces and enriched the culture, the architecture, and the gastronomy, all of them being relevant factors for encouraging tourists to visit it. Nevertheless, the heritage has been better kept in rural areas, and better preserved against external influences, where tourists have the possibility to experience the feeling of travelling back in time.

Tourism is perceived as being an important development opportunity for the rural community from the Kurdistan Regional Government and it uses different tools to promote it worldwide, mostly by the General Board of Tourism of the Kurdistan Regional Government even if their efforts are, however, incipient and undersized compared to the potential of the region.

One should not neglect the fact that the Kurdistan region is regularly associated with the feeling of insecurity for foreigners, mostly by Western mass-media which is not able to make the regional, social, and geographical differences in the region. Certainly, that drastically limits the intention of Western tourists to go visit the area, no matter how charming the opportunity to see, feel and taste Kurdish attractions may sound for them. Being located in a conflict zone, the Kurdish region is affected by the general perception and fear about terrorism. Therefore, the local authorities must assume a constant mission of communication in order to contribute to tourism development. So, besides administrative issues like building tourism infrastructure and investments in tourism facilities in the area to encourage tourism development [60], an important aspect resides in the capability of marketing the destination. This implies taking into consideration the perceived risk which influences the international decisions to travel to Kurdistan, the foreigners' attitude towards the destination, and their income [61]. Efficient destination marketing should imply participating in international tourism fairs and a constant communication about the safety of the region.

In the Kurdistan Regional Development, the link of the urban population with the rural roots is present everywhere, being a usual occurrence to meet local producers selling agricultural, food, and handmade products on the streets and/or on bazars. Also, it is quite common for urban inhabitants to often go for barbeques and sightseeing on the outskirts of the cities. As a consequence, domestic demand for rural tourism services in the region is more related to the need for quietness and rediscovery of the old culture and history-a feeling deeply present in the social life of Kurdish people.

The findings of the paper prove that tourism in the rural area of Kurdistan Regional Government is regarded rather positively by the inhabitants, being expected to have beneficial outcomes both on tourism suppliers in the region and on the region, as an entity. As such, it exhibits the potential to become an important source of sustainable development if tourism suppliers from rural areas keep creating their offers based on the abovementioned expectations of the target population.

The local residents are aware of the impacts that tourism can have on their community and they highly appreciate the positive ones: improvement of the quality of the recreation opportunities, development of the community by increasing the living standard and the quality of life.

Results indicate that tourism impacts are perceived positively as employment opportunities and well-being increase. The older residents of the rural area are willing to support the development of 
sustainable tourism because of the positive effects on the community and environment, even if they are more concerned about the negative tourism impacts (crime, pollution, traffic jams, etc.).

Similar to previous studies, it is needed to highlight the fact that even if tourism is considered to be an alternative occupation for women in the rural area, the women are less attracted to start-up a business, compared with the men [52].

The development of tourism in the rural areas of the Kurdistan Regional Government implies strategic plans that take into consideration the heritage, the cultural characteristics, and competitive advantages of the area in order for it to be sustainable and attract both national and foreign visitors. Tourist facilities (lodgings, restaurants, entertainment) should be adapted to the visitors' needs in order to gain competitive advantages. In the same time, special training programs should be developed to qualify the working force in tourism services and assure high standard quality services, which could improve the perception about the quality of the rural tourism services. The research underline important aspects related to the perception of the residents through tourism development in the area. The sustainable tourism development in a destination is highly influence by the interaction between tourists and residents. The quality of interaction between residents and tourist influence residents' perceptions regarding tourism development and acceptance and tolerance for tourists by residents [62].

This research examined the variables and factors that explained the local rural residents' attitudes and perceptions toward tourism development in the Kurdistan Regional Government. The results of the research provide helpful and important information about their support for tourism development and their future intention to get into the tourism business. This information can be used by policy-makers and tourism strategies to formulate and develop plans for sustainable rural tourism development.

Future research should be extended to either rural areas of the Kurdistan Regional Development in order to determinate the support and attitude of the local community toward tourism development, on the one hand, and to identify the satisfaction level of the tourists, on the other hand. In order to develop proper and sustainable strategies, it is important to analyze the demand for rural tourism, as well. This can provide vital information about the socio-demographic characteristics of the tourists, their preferences, and trip budget, which can be later used to develop proper tourism services and products.

Author Contributions: Conceptualization, R.H., K.S., and I.C.M.; Methodology and analysis, I.C.M. and G.O.C.; Data collecting, R.H. and K.S.; Writing, R.H., G.O.C., I.C.M., Review and editing: R.H. and F.H.A. All authors approved the final version.

Funding: This research received no external funding.

Acknowledgments: Assistance provide by Briska Jamal, Balqis Saed, Shaho Sabir, Nigar Ghafar, graduates of $\mathrm{ARD}$, during the data collection is greatly appreciated.

Conflicts of Interest: The authors declare no conflict of interest.

\section{References}

1. Diedrich, A.; Garcia-Buades, E. Local perceptions of tourism as indicators of destination decline. Tour. Manag. 2009, 30, 512-521. [CrossRef]

2. Almeida-García, F.; Pelaez-Fernandez, M.A.; Balbuena-Vazquez, A.; Cortes-Macias, R. Residents' perceptions of tourism development in Benalmadena (Spain). Tour. Manag. 2016, 54, 259-274. [CrossRef]

3. Presenza, A.; Del Chiappa, G.; Lorn, S. Residents' Engagement and Local Tourism Governance in Maturing Beach Destinations: Evidence from an Italian Case Study. J. Dest. Market. Manag. 2013, 2, 22-30. [CrossRef]

4. Abdollahzadeh, G.; Sharifzadeh, A. Rural Residents' Perceptions toward Tourism Development: A Study from Iran. Int. J. Tour. Res. 2014, 16, 126-136. [CrossRef]

5. Vargas-Sánchez, A.; Plaza-Mejía, M.A.; Porras-Bueno, N. Community Understanding Residents' Attitudes toward the Development of Industrial Tourism in a Former Mining. J. Travel Res. 2008, 47, 373-387. [CrossRef]

6. Dutescu, A.; Popa, A.F.; Ponorîcă, A.G. Sustainability of the Tourism Industry, Based on Financial Key Performance Indicators. Amfiteatru Econ. 2014, 16, 1048-1062. 
7. Nistoreanu, P.; Tănase, M.O. The Relationship between the Integrated Tourism Development of a Region and the Respective Local Communities of Romania. A Moral Approach. Amfiteatru Econ. 2008, 109, 41-45.

8. Nunkoo, R.; So, K.K.F. Residents' Support for Tourism: Testing Alternative Structural Models. J. Travel Res. 2015, 1-15. [CrossRef]

9. Kyle, S.M.; Woosnamb, M.; Musa, T.P.G.; Hamzahc, A. The effect of residents' personality, emotional solidarity, and community commitment on support for tourism development. Tour. Manag. 2017, 63, 242-254. [CrossRef]

10. Sinclair-Maragh, G. Demographic analysis of residents' support for tourism development in Jamaica. J. Dest. Market. Manag. 2017, 6, 5-12. [CrossRef]

11. Rasoolimanesh, S.M.; Ringle, C.M.; Jaafar, M.; Ramayah, T. Urban vs. rural destinations: Residents' perceptions, community participation and support for tourism development. Tour. Manag. 2017, 60, 147-158. [CrossRef]

12. Campón-Cerro, A.M.; Folgado-Fernández, J.A.; Hernández-Mogollón, J.M. Rural Destination Development Based on Olive Oil Tourism: The Impact of Residents' Community Attachment and Quality of Life on Their Support for Tourism Development. Sustainability 2017, 9, 1624. [CrossRef]

13. Eshliki, S.A.; Kaboudi, M. Community Perception of Tourism Impacts and Their Participation in Tourism Planning: A Case Study of Ramsar, Iran. Proc. Soc. Behav. Sci. 2012, 36, 333-341. [CrossRef]

14. Min, Z.; Xiaoli, P.; Bihu, W. Research on Residents' perceptions on Tourism Impacts and Attitudes-A Case Study of Pingyao Ancient City. In Proceedings of the 6th Conference of the International Forum on Urbanism (IFoU): Tourbanism, Barcelona, Spain, 25-27 January 2012; pp. 1-10.

15. Mohammadi, M.; Khalifah, Z.; Hosseini, H. Local People Perceptions toward Social, Economic and Environmental Impacts of Tourism in Kermanshah (Iran). Asian Soc. Sci. 2010, 6, 220-225. [CrossRef]

16. Cañizares, S.M.; Núñez Tabales, J.M.; García, F.; Fernando, J. Local residents' attitudes towards the impact of tourism development in Cape Verde. Tour. Manag. Stud. 2014, 10, 87-96.

17. Lo, M.C.; Ramayah, T.; Hui, H.L.H. Rural Communities Perceptions and Attitudes towards Environment Tourism Development. J. Sustain. Dev. 2014, 7, 84-94. [CrossRef]

18. Kim, S.; Park, E.; Phandanouvong, T. Barriers to Local Residents' Participation in Community-Based Tourism: Lessons from Houay Kaeng Village in Laos. In SHS Web of Conferences; EDP Sciences: Les Ulis, France, 2014; Volume 12.

19. Wang, Y.; Pfister, R.E. Residents' Attitudes toward Tourism and Perceived Personal Benefits in a Rural Community. J. Travel Res. 2008, 47, 84-93. [CrossRef]

20. Hanafiah, M.H.; Jamaluddin, M.R.; Zulkifly, M.I. Local Community Attitude and Support towards Tourism Development in Tioman Island, Malaysia. Proc. Soc. Behav. Sci. 2013, 105, 792-800. [CrossRef]

21. Andereck, K.L.; Valentine, K.V.; Knopf, R.C.; Vogt, C.A. Residents' perceptions of community tourism impacts. Ann. Tour. Res. 2005, 32, 1056-1076. [CrossRef]

22. Lee, T.H. Influence analysis of community resident support for sustainable tourism Development. Tour. Manag. 2013, 34, 37-46. [CrossRef]

23. Stylidis, D.; Biran, A.; Sit, J.; Szivas, E.M. Residents' support for tourism development: The role of residents' place image and perceived tourism impacts. Tour. Manag. 2014, 45, 260-274. [CrossRef]

24. Bestard, A.B.; Nadal, J.R. Attitudes toward Tourism and Tourism Congestion. Rég. Dév. 2007, 25, $193-207$.

25. Garau-Vadell, J.B.; Díaz-Armas, R.; Gutierrez-Taño, D. Residents' Perceptions of Tourism Impacts on Island Destinations: A Comparative Analysis. Int. J. Tour. Res. 2014, 16, 578-585. [CrossRef]

26. McGehee, N.G.; Andereck, K.L. Factors predicting rural residents' support of tourism. J. Travel Res. 2004, 43, 131-140. [CrossRef]

27. Dorcheh, S.A.; Badaruddin, M. Local Perception of Tourism Development: A Conceptual Framework for the Sustainable Cultural Tourism. J. Manag. Sustain. 2013, 3, 31-39. [CrossRef]

28. Brida, J.G.; Osti, L.; Faccioli, M. Residents' perception and attitudes towards tourism impacts A case study of the small rural community of Folgaria (Trentino-Italy). Benchmark. Int. J. 2011, 18, 359-385. [CrossRef]

29. Nejati, M.; Mohamed, B.; Omar, S.I. Locals' perceptions towards the impacts of tourism and the importance of local engagement: A comparative study of two islands in Malaysia. Rev. Tour. Res. (eRTR) 2015, 12, 135-146.

30. Chandralal, K.P.L. Impacts of Tourism and Community Attitude towards Tourism: A Case Study in Sri Lanka. South Asian J. Tour. Herit. 2010, 3, 41-49. 
31. Jaafar, M.; Bakri, N.M.; Rasoolimanesh, S.M. Local Community and Tourism Development: A Study of Rural Mountainous Destinations. Mod. Appl. Sci. 2015, 9, 399-408. [CrossRef]

32. Jafari, M.; Pour, S.A. Effects of economic, social and environmental factors of tourism on improvement of Perceptions of local population about tourism: Kashan touristic city, Iran. Ayer 2014, 4, 72-84.

33. Naidoo, P.; Sharpley, R. Local perceptions of the relative contributions of enclave tourism and agritourism to community wellbeing: The case of Mauritius. J. Destin. Mark. Manag. 2015, 5, 16-25. [CrossRef]

34. Ramseook-Munhurrun, P.; Naidoo, P. Residents' Attitudes toward Perceived Tourism Benefits. Int. J. Manag. Market. Res. 2011, 4, 45-56.

35. Pavel-Nedea, A.; Dona, I. Assessement of Residents' Attitudes towards Tourism and His Impact on Communities in the Danube Delta. Scientific Papers. Series Management. Econ. Eng. Agric. Rural Dev. 2017, $17,275-280$.

36. Alhasanat, S.A.; Hyasat, A.S. Sociocultural Impacts of Tourism on the Local Community in Petra, Jordan. Jordan J. Soc. Sci. 2011, 4, 1.

37. Cañizares, S.M.S.; Castillo Canalejo, A.M.; Núñez Tabales, J.M. Stakeholders' perceptions of tourism development in Cape Verde, Africa. Issues Tour. 2015, 1-15. [CrossRef]

38. Tosun, C. Host Perceptions of Impacts a Comparative Tourism Study. Ann. Tour. Res. 2002, 29, $231-253$. [CrossRef]

39. Sinclair-Maragh, G.; Gursoy, D.; Vieregge, M. Residents' perceptions toward tourism development: A factor-cluster approach. J. Destin. Mark. Manag. 2015, 4, 36-45. [CrossRef]

40. Royo, M.; Ruiz, M.E. Actitud del residente hacia el turismo y el visitante: Factores determinantes en el turismo y excursionismo rural cultural. Cuadernos Turismo 2009, 23, 217-236.

41. Musa, G. Residents attitudes and perception towards tourism development: A case study of Masooleh, Iran. Tour. Manag. 2009, 29, 1233-1236. [CrossRef]

42. Aref, F.; Redzuan, M.; Gill, S.S. Community Perceptions toward Economic and Environmental Impacts of Tourism on Local Communities. Asian Soc. Sci. 2009, 5, 130-137. [CrossRef]

43. Eraqi, M.I. Local Communities' Attitudes towards Impacts of Tourism Development in Egypt. Tour. Anal. 2007, 12, 191-200. [CrossRef]

44. Mohammadi, M.; Kalifah, Z. Local Community Attitudes toward Social and Economic Impacts of Tourism: A case study of Bisotun, Iran. World Appl. Sci. J. 2010, 10, 1160-1166.

45. Olya, H.G.T.; Gavilyan, Y. Configurational Models to Predict Residents' Support for Tourism Development. J. Travel Res. 2016, 56, 893-912. [CrossRef]

46. Alipour, H.; Olya, H.G.T.; Forouzan, I. Environmental Impacts of Mass Religious Tourism: From Residents' Perspectives. Tour. Anal. 2017, 22, 167-183. [CrossRef]

47. Ramdasa, M.; Mohameda, B. Impacts of tourism on environmental attributes, environmental literacy and willingness to pay: A conceptual and theoretical review. Procedia Soc. Behav. Sci. 2014, 144, 378-391. [CrossRef]

48. Kostas, K.; MacGinnis, J.; Ur, J. (Eds.) Archaeological Projects in the Kurdistan Region in Iraq; The Directorate of Antiquities of Kurdistan: Erbil, Iraq, 2015.

49. Hair, J.; Black, W.; Babin, B.; Anderson, R.; Tatham, R. Multivariate Data Analysis, 6th ed.; Pearson Prentice Hall: Uppersaddle River, NJ, USA, 2006.

50. Kaiser, H.F. Index of factorial simplicity. Psychometrika 1974, 39, 31-36. [CrossRef]

51. Ding, C.; He, X. K-means clustering via principal component analysis. In Proceedings of the 21st International Conference on Machine Learning, Banff, AB, Canada, 4-8 July 2004; pp. 29-37.

52. Tabachinick, B.G.; Fidell, L.S. Using Multivariate Statistics, 2nd ed.; Harper \& Row: Cambridge, UK, 1989.

53. Muresan, I.C.; Oroian, C.F.; Harun, R.; Arion, F.H.; Porutiu, A.; Chiciudean, G.O.; Todea, Al.; Lile, R. Local residents' attitude toward sustainable rural tourism development. Sustainability 2016, 8, 100. [CrossRef]

54. Andriotis, K. Community groups' perceptions of and preferences for tourism development: Evidence from Crete. J. Hosp. Tour. Res. 2005, 29, 67-90. [CrossRef]

55. Kuvan, Y.; Akan, P. Residents' attitude toward general and forest-related impact of tourism: The case of Belek, Antalya. Tour. Manag. 2005, 26, 691-706. [CrossRef]

56. Cavus, S.; Tanrisevdi, A. Residents' attitudes toward tourism development: A case study in Kusadasi, Turkey. Tour. Anal. 2002, 7, 259-269. [CrossRef] 
57. Deng, J.; Arbogast, D.; Selin, S. Community-based tourism planning: An application of the APPA approach to Anstead, West Virginia. Tour. Anal. 2011, 16, 601-615. [CrossRef]

58. Charles, V.; Gherman, T. Factors Influencing Peruvian Women to Become Entrepreneurs. World Appl. Sci. J. 2013, 27, 1345-1354. [CrossRef]

59. Iakovidou, O.; Koutsou, S.; Partalidou, M.; Emmanouilidou, M. Women entrepreneurs in rural Greece: Do they come from the same "neck of the woods"? Locals, Daughters-in-law and Urban-newcomers. New Medit 2012, 2, 58-64.

60. Buultjensa, J.W.; Ratnayakeb, I.; Athula Chammika Gnanapalab, W.K. Post-Conflict tourism development in Sri Lanka: Implications for building resilience. Curr. Issues Tour. 2015, 19, 353-372. [CrossRef]

61. Sönmez, S.; Graefe, A.R. Influence of Terrorism Risk on Foreign Tourism Decisions. Ann. Tour. Res. 1998, 25, 112-144. [CrossRef]

62. Armenski, T.; Dragicevic, V.; Pejovic, L.; Lukic, T.; Djurjec, B. Interaction between Tourists and Residents: Influence on Tourism Development. Pol. Sociol. Rev. 2011, 173, 107-118. [CrossRef]

(C) 2018 by the authors. Licensee MDPI, Basel, Switzerland. This article is an open access article distributed under the terms and conditions of the Creative Commons Attribution (CC BY) license (http:/ / creativecommons.org/licenses/by/4.0/). 